\title{
TELÍTETLEN TALAJOK HIDRAULIKUS JELLEMZŐINEK A LABORATÓRIUMI VIZSGÁLATA
}

\section{LABORATORY ASSESSMENT OF THE HYDRAULIC CHARACTERISTICS OF UNSATURATED SOILS}

\author{
Botoș Marius Lucian ${ }^{1}$, Gobesz Ferdinánd-Zsongor ${ }^{2}$ \\ ${ }^{I}$ Kolozsvári Müszaki Egyetem, Építömérnöki Kar, Tartószerkezetmechanikai \\ Tanszék, 400027, Románia, Kolozsvár, Gh. Baritiu u. 25, I. em., 147, Tel. +40-264- \\ 401517,marius.botos@mecon.utcluj.ro \\ ${ }^{2}$ Kolozsvári Müszaki Egyetem, Építömérnöki Kar, Tartószerkezetmechanikai \\ Tanszék, 400020, Románia, Kolozsvár, C. Daicoviciu u. 15, III. em., 305, Tel. +40- \\ 264-401351,go@mecon.utcluj.ro
}

\begin{abstract}
It is a brief description of a method used in laboratory conditions to measure the soil-water characteristic curves in order to establish the hydraulic properties of unsaturated soils. The assembled automated setup allows the assessment of the saturation degree of soil samples subjected to different suctions.

Keywords: soil, water, unsaturated, testing

\section{Összefoglalás}

Egy olyan laboratóriumi módszer és berendezés rövid ismertetése, melyet a talaj-víz jelleggörbéinek a mérésére alkalmazunk, hogy a telítetlen talajok hidraulikus jellemzőit meg lehessen állapítani. Az összeállított automatizált felszerelés különböző szívóhatásoknak alávetett talajminták telítettségi fokát hivatott értékelni.
\end{abstract}

Kulcsszavak: talaj, viz, telitetlen, vizsgálat

\section{Bevezetés}

A talajvíz jelenléte és mozgása az egyik legfontosabb kérdés ami a földszerkezetek viselkedését befolyásolja. A klasszikus elmélet szerint a szivárgások vizsgálatából lehet a pórusbeli víznyomásra, beszürődött vízmennyiségre, hidraulikus gradiensre vonatkozó információkat kapni, valamint a telített részek egyértelmü körülhatárolása a beszivárgási görbe kiszámításával is ez alapján történik. A telítetelen talajok elméletének az alkalmazása akkor válik szükségessé, amikor a peremfeltételek változása jelentős (pl. kisméretű földgátaknál, ha a tárolt vízmennyiség szintjének nagy az ingadozása, vagy, ha csapadékból beszivárgó víz hat ingatag lejtőkre).

Ilyenkor az első lépés a hidraulikus jellemzők meghatározása (telítettségi fok, tárolási kapacitás, na meg az üzemeltetés során bekövetkezhető különböző szívásokra a permeabilitási együtthatók). A telítetlen vagy részlegesen telített talajok hidraulikus jellemzőit többféle képpen lehet meghatározni: közvetlen laboratóriumi módszerekkel stacionárius körülmények között [1], 
nem-stacionárius környezetben [2], vagy közvetlenül a terepen [3].

A közvetlen eljárások nagyon költségesek és hosszadalmasak, ezért az idők folyamán több közvetett (elméleti) módszer lett kifejlesztve a szívóhatástól függő hidraulikus jellemzők megállapítására. Ezek a módszerek a talaj vízvisszatartási görbék (WRC), illetve a talaj-víz jelleggörbék (SWC) meghatározására alapozódnak. Ezek a görbék jellemzik a vizsgált talaj telítettségi fokát különböző szintü szívóhatásokra.

A vízvisszatartási görbék laboratóriumbeli meghatározása komoly felszerelést és képzett személyzetet igényel. A talaj-víz jelleggörbék meghatározáshoz feszültségmérők segítségével szitás szívás esetén, villamos- vagy hőérzékelőket, vagy akár szürőpapírt lehet használni a tengelyeltolási módszer [4] alkalmazásával (a feszültségmérőkkel $100 \mathrm{kPa}$-os nagyságrendü negatív pórusbeli víznyomást lehet terepen vagy laboratóriumban mérni). Ez a tengelyeltolási módszer sajátos felszerelést igényel, mely megengedi, hogy különböző nyomásokat hozzanak létre és ezeket fenntartsák addig, amíg kialakul a gáz-víz egyensúly. Amennyiben hő- vagy áramérzékelőket használnak, ezeket hőforrással ellátott gipsz elemekhez vagy fémrudakhoz csatlakoztatják. A szürőpapíros eljárásnál a talajpróba nedvességét mérik különböző szívóhatások alatt, a száraz felületre fektetett szürőpapírhoz viszonyítva.

\section{Elméleti háttér}

Mint ismeretes, a nem permanens mozgást telítetlen közegekben Richard egyenletével lehet meghatározni (a vízáteresztési együtthatók meg a kapilláris kapacitás segítségével, a szívás függvényében).

A telítettségi fokot az alábbi képlet adja:

$$
S_{e}=\frac{\theta-\theta_{r}}{\theta_{s}-\theta_{r}}
$$

ahol $\theta_{s}$ jelöli a nedvességet telített állapotban (90-92\%) és $\theta_{r}$ a maradék nedvességet (1500 kPa szívásnál visszamaradt nedvesség a talajmintában). A $\theta$ nedvességet, vagy a $S_{e}$ telítettségi fokot a tengelyeltolási kísérleti módszerrel lehet különböző szintü szívóhatásokra megállapítani. Ahhoz, hogy egy deriválható folytonos függvényt kapjunk, a szakirodalom több közelítési egyenletet is kínál. A mi esetünkben Brooks és Corey [5], illetve van Genuchten [6] egyenleteit választottuk. A probléma akkor tekinthető részben megoldva, amikor az alakparaméterek értékét úgy sikerül meghatározni, hogy a telítettségi fokot leíró függvény minél pontosabban fedje a kísérleti mérések eredményeit. Miután kiválasztjuk azt a modellt, amelyik a legjobban közelít a kísérleti adatokhoz, az alakparamétereket felhasználhatjuk a relatív vízátbocsátási tényező kiszámításához (Burdine, vagy Mualem modelljére [7] alkalmazva Brooks és Corey, vagy van Genuchten egyenleteit). A telítetlen talaj vízátbocsátási tényezőjét úgy kapjuk meg, hogy megszorozzuk a telített közeg permeabilitási együtthatóját a relatív vízátbocsátási tényezővel.

\section{Gyakorlati alkalmazás}

Az említett eljárások szerint, a közvetlen módszerek alkalmazásához meg kell határozni a talaj-víz jelleggörbéket és a vízátbocsátási együtthatót telített állapotban a laboratóriumban. Porózus és laza talajoknál konstans gradiensü, kis vízáteresztő képességü talajmintáknál pedig változó gradiensű vízátbocsátásmérőt használnak e célra. Az együttható kiszámításához Darcy képletét lehet alkalmazni (mely többféleképpen írható, attól függően, hogy mely értékeket mérjük):

$$
q=v \cdot A=K_{t e l} \cdot i \cdot A
$$

ahol $q$ az áteresztett vízmennyiség, $K_{t e l}$ a vízáteresztési együttható telített állapotban, $i$ a hidraulikus gradiens és $A$ a vízáteresztő 
metszet mérete. Az áteresztett víz mennyiségét egy mikrokontrollerhez csatlakoztatott precizíós mérleggel lehet mérni, a hidraulikus gradienst pedig többféleképpen is ki lehet egyszerüen számítani.

Amennyiben változó gradiensű vízátbocsátásmérőt használunk, az áteresztett víz mennyiségét az átlátszó ( $d$ átmérőjü) függőleges csőben (1. ábra) $\Delta \mathrm{t}$ időintervallum alatt észlehető vízszint $\Delta h$ változása alapján kaphatjuk meg:

$$
q=\frac{\Delta h \cdot \pi \cdot d^{2}}{4 \cdot \Delta t}
$$

Ha automata olvasás történik (érzékelő segítségével), akkor az előbbi képlet alakja a következő lesz:

$$
q=\frac{\Delta h \cdot \pi \cdot d^{2}}{\gamma \cdot 4 \cdot \Delta t}
$$

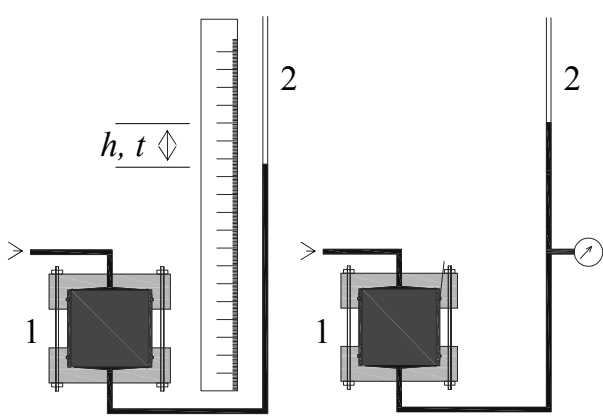

1. ábra. Kézi meg automata adatrögzitésü vizátbocsátásmérö sémája. 1 - a talajmintát tartalmazó kamra, 2 - átlátszó cső.

A tengelyeltolási módszer alkalmazásához az alsó szürőt egy HAES (High Air Entry Stone) lappal helyettesítjük a kamrában. A szerkezete révén, ez a (tulajdonképpen kerámia) lap telített állapotban nem engedi át a levegőt egy bizonyos (gyárilag meghatározott) nyomás alatt a tartalmazott pórusok mérete és alakja miatt, viszont, addig amíg a pórusaiban lévő víz érintkezésben van a próbatestben lévő vízzel, átengedi a vizet. A talajmintán átszürődő víz- mennyiséget egy elektronikus mérleggel, vagy térfogatilag egy preciziós büretta segítségével lehet meghatározni.

Alacsony szívóértékek esetén a légnyomás beállítása és fenntartása az egyensúlyi állapot meghatározásához elég nehéz egy szabályozóval. 20-30 kPa alatti szívásra lehet egy nyomásgerjesztő nélküli berendezést alkalmazni, légköri nyomást tartva a kamrában és olyan szívóhatást kelteni a kerámia lap alján, amit egy kimeneti túlfolyóval (a távozó víz szintjének állandóságával) azonos értéken lehet tartani.

Mivel ezek a folyamatok nagyon hoszszan tartanak és időnként elengedhetetlen a berendezés ellenőrzése az egyensúlyi állapot végett, az automatizálást nem lehet elkerülni. Párhuzamosan több talajpróbán végezve ezeket a méréseket, az egyensúly megállapítása meg a talajmintára gyakorolt nyomás folytonos szinten tartása sok időt és figyelmet követel.

A tanszékünk vízépítési laboratóriumában ezért egy olyan berendezést állítottunk össze, amin egyszerre 10 talajmintát lehet párhuzamosan vizsgálni, egy kompresszor és egy mikrokontroller segítségével. A mikrokontroller szerepe a következő fázisokban fontos:

- a nyomás szabályozása egy előre megállapított értéken (végighaladva minden elöre ütemezett mérési szakaszon);

- a bürettában vagy a piezométerben levő víz szintjének a megállapítása az átfolyt víztérfogat méréséhez, valamint ahhoz, hogy mikor lehet a következő nyomásszintre térni;

- a mágnesszelepek párhuzamos vezérlése (ezek segítségével lehet pontosan mérni mindegyik talajmintában különkülön a vizet, minden mért és lementett egyensúlyi szintre);

- az adatok továbbítása egy adatbázisba, majd a jelleggörbék megjelenítése;

- a függvény legalkalmasabb folytonossági egyenletének a kiválasztási algo- 
ritmusának a futtatása, az egyezési paraméterek meghatározása;

- az összes hidraulikus jellemző kiszámítása és a változási görbék ábrázolása.

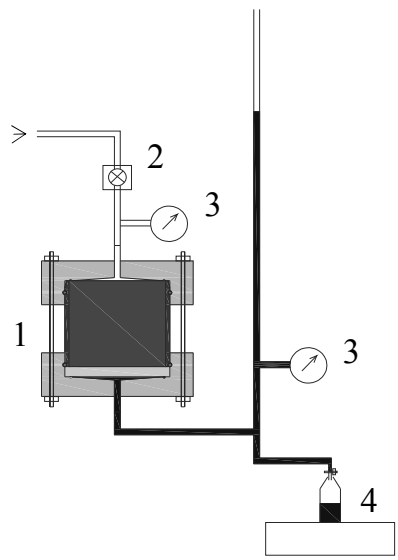

2. ábra. A laboratóriumi berendezésünk sémája. 1-a talajmintát tartalmazó kamra (a HAES lappal alul), 2-nyomásszabályozó, 3-nyomásérzékelö, 4-mérleg.
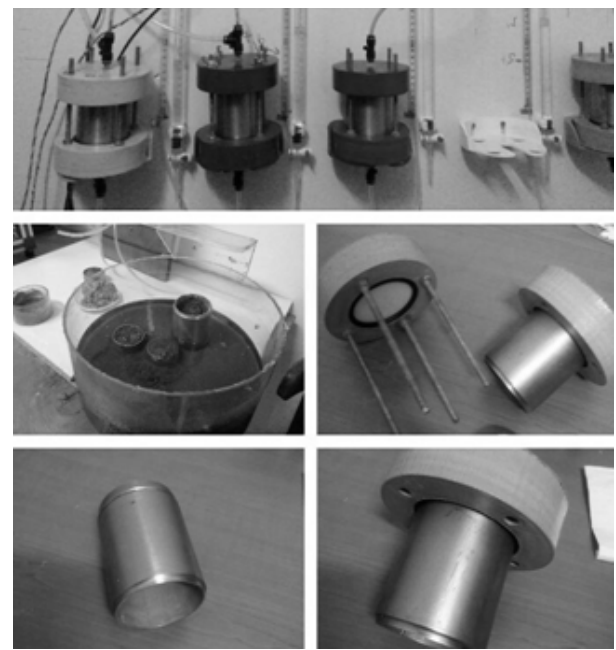

3. ábra. A laboratóriumi berendezésünk részei.

Ez a rendszer lehetővé teszi a külső beavatkozást is (vezérlést, monitorizálást) egy webes felületen keresztül, elektronikus posta-üzenettel értesítve a vizsgálat végéről egyes mintáknál. Az automatizálásnak köszönhetően minden nyomástartományra megalkotja és rögzíti a kifolyó térfogatok időbeli változási görbéit, hogy meg lehessen határozni a diffúzivitást.

\section{Következtetések}

A tanszék laboratóriumában létrehozott kísérleti berendezés alkalmasnak bizonyult arra, hogy a mesteri szinten kutató hallgatók mellett szakemberek is igénybe vegyék a telítetlen talajok vizsgálatához. Arra is lehetőséget kínál, hogy a jelleggörbék alapján, a hidraulikus jellemzők mellett gázáteresztési képességgel, nyírási ellenállással, vagy hővezetési képességgel kapcsolatos kérdésekkel is foglalkozzunk.

\section{Szakirodalmi hivatkozások}

[1]Klute, A.: Laboratory measurement of hydraulic conductivity of unsaturated soil. Methods of Soil Analysis, Mono. 9, Part 1. American Society of Agronomy, Madison, WI, USA, 1965, 253 - 261.

[2]Hamilton, J. M., Daniel, D. E., Olson, R. E.: Measurement of hydraulic conductivity of partially saturated soils. Permeability and Groundwater Contaminant Transport. ASTM Special Tech. Publ. 746, 1981, 182 - 196.

[3] Watson, K. K.: An instantaneous profile method for determining hydraulic conductivity of unsaturated porous materials. Water Resources Research 2, 1966, 709-715.

[4] Vanapalli S. K., Nicotera M.V., Sharma R.S.: Axis translation and negative water column techniques for suction control. Laboratory and Field Testing of Unsaturated Soils, Springer, 2009, 33-49.

[5]van Genuchten, M. T.: A closed-form equation for predicting the hydraulic conductivity of unsaturated soils. Soil Science Society of America Journal 44, 1980, 892-898.

[6] Brooks, R. H., Corey, A. T.: Hydraulic properties of porous medium. Hydrology Paper 3. Colorado State University, Fort Collins, USA, 1964.

[7] Mualem, Y.: A new model for predicting the hydraulic conductivity of unsaturated porous media. Water Resources Research 12 (3), 1976, 513-522. 